\title{
SOIL NUTRITION MANAGEMENT AND PREDATION BY CHEILOMENES SEXMACULATA (COLEOPTERA: COCCINELLIDAE) IMPACTS ON APHIS GLYCINES (HOMOPTERA: APHIDIDAE)
}

\author{
Rosma Hasibuan' ${ }^{1}$ \& Jamalam Lumbanraja ${ }^{2}$
}

\begin{abstract}
Soil nutrition management and predation by Cheilomenes sexmaculata (Coleoptera: Coccinellidae) impacts on Aphis glycines (Homoptera: Aphididae). Understanding how soil nutrient availability and natural enemies impacts on aphid populations are important for soybean aphid, Aphis glycines Matsumura (Homoptera: Aphididae), management. Studies were conducted to examine the effect of soil nutrient management and predaceous coccinellid beetle, Cheilomenes sexmaculata (Fabr.), (Coleoptera: Coccinellidae) on A. glycines population. The plot size of $300 \mathrm{~m}^{2}$ was set up into 12 plots consisting four treatments and three replications. The treatments were the combination of NPK (urea $100 \mathrm{~kg} \mathrm{ha}^{-1}+\mathrm{SP}-36200 \mathrm{~kg} \mathrm{ha}^{-1}+\mathrm{KCl}_{200}$ $\left.\mathrm{kg} \mathrm{ha}^{-1}\right)$ levels, dolomite $\left(4\right.$ ton ha $\left.{ }^{-1}\right)$, compost $\left(10\right.$ ton ha $\left.^{-1}\right)$, and chicken manure $\left(10\right.$ ton ha $\left.{ }^{-1}\right)$. While, the predator's potential of $C$. sexmaculata was measured both in the field and laboratory conditions. The results of the studies indicated that soil nutrition treatments had significant effects on the plant performances: leaf numbers; pod numbers; and plant height. In line with this result, there were significant effects of soil nutrient treatments on the amount of plant nutrient: $\mathrm{C}, \mathrm{N}, \mathrm{P}, \mathrm{K}, \mathrm{C}, \mathrm{Ca}$, and $\mathrm{Mg}$. The positive correlation coefficient was observed between the aphid population and nitrogen content, while the significant negative correlation found on between aphid population and the calcium and magnesium content. Meanwhile, the mean number of soybean aphids (A. glycines) consumed by C. sexmaculata increased from 8.915 to 40.64 aphids, with an average $26.35 \pm 3.16$ aphids. The mean numbers of aphids consumed by predator were significantly influenced by prey densities. The exclosure study result showed that the densities of A. glycines in caged plants was higher than that in un-caged plants. In the no-cage treatments, natural enemies had complete access to soybean aphids and caused the total reduction (100\%) of $A$. glycines density by the $8^{\text {th }} \mathrm{wk}$ sample period. These findings suggest that reducing the amount of synthetic chemical fertilizer NPK can be supplemented with natural organic materials such as composts and chicken manure and natural occurring predator, C. sexmaculata, is an important natural enemy of the soybean aphid.
\end{abstract}

Key words: Aphis glycines, Cheilomenes sexmaculata, soil nutrient management, predation efficiency

\section{INTRODUCTION}

The soybean aphid, Aphis glycines Matsumura (Hemiptera: Aphididae), is a serious pest throughout the soybean growing regions in many parts of world including Indonesia (van den Berg et al., 1997; Liu et al., 2004, Blackman \& Eastop, 2000; Ragsdale et al., 2007; Wu et al., 2004; McCornack et al., 2004). Previous studies reported that soybean that severely infested by soybean aphids may be stunted or turned brown and die (Alleman et al., 2002; Clark \& Perry, 2002; Wang \& Ghabrial, 2002; Myers et al., 2005a; Ragsdale et al., 2007; van den Berg et al., 1997). In addition to yield reduction, the soybean aphid is also capable of transmitting several viruses that infect soybean, such as soybean dwarf virus and soybean mosaic virus (Clark \& Perry, 2002; Halbert et al., 1996; Hill et al., 2001; Hill et al., 1987; Irwin et al., 2000). A study by Wang \& Ghabrial (2002) found that soybeanseed yields were reduced by $27.8 \%$ and plant height decreased by $20.2 \mathrm{~cm}$ in aphid-infested plants as compared to that in non-infested plants. Moreover McCornack et al. (2008) reported that the soybean aphids is capable of reducing soybean yield up to $40 \%$ during severe outbreaks.

Since World War II, soil and pest management practices have changed dramatically including an increased use in synthetic fertilizers and pesticides to increase crop yields. At the same time, some studies have suggested that the excessive use of these

\footnotetext{
${ }^{1}$ Department of Plant Protection, Faculty of Agriculture, University of Lampung,

Jl. Prof. Sumantri Brojonegoro No 1 Bandar Lampung, 35145. E-mail : rosma@unila.ac.id

${ }^{2}$ Department of Soil Science, Faculty of Agriculture, University of Lampung,

Jl. Prof. Sumantri Brojonegoro No 1 Bandar Lampung, 35145
} 
agrochemicals may actually increase pest problems in the long run (Altieri \& Nicholls, 2003). Conventional broad-spectrum insecticide has been used excessively to protect soybean from yield loss (Alteri et al., 2003; Hsu et al., 2009; Letourneau et al., 1996; Karungi et al., 2006; Oelhaf, 1978; Merrill, 1983; Scow et al., 1994). According to Myers et al. (2005b), in many parts of soybean-growing countries, soybean growers applied insecticide as many as four times in one season to avoid yield loss. High frequent applications of broad-spectrum pesticides can lead to the buildup of aphid resistance to chemicals, resulting in more chemicals being used with potentially severe environmental side effects (Conway \& Pretty, 1991; Altieri \& Nicholls, 2003). Moreover Kraiss \& Cullen (2008) found that insecticide pyrethrins were highly toxic to first instars of multicolored Asian lady beetle, Harmonia axyridis (Pallas), a key biological control agents of soybean aphids. Pesticide application can alter the pest and predator or parasitoid ratios in agroecosystem inflicting more harm than good. Concerning the synthetic fertilizers, some studies have also documented that shift from organic soil management to chemical fertilizers has increased the potential of certain insect species and diseases to cause economic losses (Alteri et al., 2003; Hsu et al., 2009; Letourneau et al., 1996; Karungi et al., 2006; Oelhaf, 1978; Merrill, 1983; Scow et al., 1994). Moreover they stated that excessive use of inorganic fertilizers, can cause nutrient imbalances and lower pest resistance.

Greater research attention has been given to reduce the use chemical fertilizers and pesticides (Altieri \& Nicholls, 2003; Hsu et al., 2009; Letourneau et al., 1996; Karungi et al., 2006; Myers et al., 2005). Cultural methods such as crop fertilization can affect plant susceptibility to insect pests by altering plant tissue nutrient levels (Meyer, 2000). Soil fertility management can have several effects on plant quality, which in turn, can affect insect abundance and subsequent levels of herbivore damage (Phelan et al., 1996; Alyokhin \& Atlihan, 2005). Many studies have indicated that the ability of a crop plant to resist or tolerate insect pests and diseases is tied to optimal physical, chemical and mainly biological properties of soils (Lockeretz et al., 1981; Reganold et al., 1987; Eigenbrode \& Pimentel, 1988; Stanhill, 1990; Karungi et al., 2006).

In addition to nutrient management, one way to reduce the reliance on agrochemical, particularly pesticide, application is to maximize the role of natural control agents (Zehnder et al., 2007; Rutledge et al., 2004). Natural enemies are thought to be the most significant biotic factor in regulating A. glycines populations (Fox et al., 2004; Rutledge \& O'Neil, 2006; van den Berg et al., 1997; Wu et al., 2004). Among the natural enemies, predators have been considered the most important one to control A. glycines (Fox et al., 2004; Mignault et al., 2006; Rutledge et al., 2004; Rutledge \& O'Neil, 2006). Predaceous coccinellid beetle species, six-spotted zigzag ladybird Cheilomenes sexmaculata (Fabricius) (syn. Menochilus sexmaculatus (Fabricius)) (Coleoptera: Coccinellidae) is a promising alternative control agent for the soybean aphid (Agarwal \& Yasuda, 2000; Bind, 1998; Cartwright et al., 2007; Omkar \& Bind, 2004). Many studies have indicated that $C$. sexmaculata is one of the most commonly occurring predator in the soybean field (Agarwala \& Bardhanroy, 1997; Agarwal \& Yasuda, 2000; Bind, 1998; Rutledge et al., 2004; Rutledge \& O'Neil, 2006). Therefore, there is a need to develop soybean aphid management tools and strategies that do not solely rely on agrochemicals. In response to $A$. glycines problem, the laboratory and field experiments were conducted to study the impact of soil nutrient management and naturally occurring predators, $C$. sexmaculata on soybean aphid population.

\section{MATERIALS AND METHODS}

Soil Nutrition Experiment. The experiment was conducted at the University of Lampung campus from July to November 2009. The whole plot area used was $300 \mathrm{~m}^{2}(20 \times 15 \mathrm{~m})$. The treatments were laid out in plots, each measuring of $2 \times 1.5 \mathrm{~m}$ with $0.5 \mathrm{~m}$ furrows spacing. The soybean variety used in this experiment was Anjasmoro. Prior to planting, rhizobium-root nodules were introduced to the soil to ensure the optimal plant growth. Soybean was planted in $10 \times 40 \mathrm{~cm}$ spacing rows by placing three seeds at each hole. Two weeks later (Vc stage as described by Fehr \& Caviness (1977)), each hill was thinned to two seedlings per stand.

The treatments consisted of the following soil amendments: $\mathrm{I}=100 \%$ chemical fertilizer NPK (urea $100 \mathrm{~kg} \mathrm{ha}^{-1}+$ SP-36 $200 \mathrm{~kg} \mathrm{ha}^{-1}+\mathrm{KCl} 200 \mathrm{~kg} \mathrm{ha}^{-1}$ $(\sim 100 \% \mathrm{NPK})$; II $=75 \%$ chemical fertilizer NPK + compost 20 ton ha ${ }^{-1}(\sim 75 \% \mathrm{NPK}+$ comp. $) ; \mathrm{III}=50 \%$ chemical fertilizer NPK + compost 10 ton $\mathrm{ha}^{-1}+$ dolomite 4 ton $\mathrm{ha}^{-1}(\sim 50 \% \mathrm{NPK}+50 \%$ comp. + dol $) ; \mathrm{IV}=50 \%$ chemical fertilizer NPK + compost 10 ton ha $^{-1}+$ chicken manure 10 ton $\mathrm{ha}^{-1}(\sim 50 \% \mathrm{NPK}+50 \%$ comp. $+\mathrm{CM})$. The treatments were arranged in the Randomized Complete Block Design (RCBD) and each treatment was replicated three times. The plots were maintained with no insecticide application and were hand weeded 
periodically. As soybean plants reached the V2 stage (three weeks after planting), plants were infested with soybean aphid Aphis glycines (Hemiptera: Aphididae). Soybean aphids used in this study were from a laboratory colony which previously collected from soybean fields. After aphid infestation, ten plants were selected randomly from each plot as a sample site. Every week, each plant sample was visually examined, and number of soybean aphid and natural enemies were counted and plant phenology was recorded using the method by Fehr et al. (1971). Seven weeks after planting (full bloom stage $=\mathrm{R} 1)$, the height of each plant sample was measured and numbers of leaves were also recorded. At the end of sampling period, the number of pods were recorded.

In addition to biological parameters, chemical parameters of soybean plants and soil were also measured. Plant tissue and soil samples were taken from each plot and analyzed at the Soil Science Laboratory, College of Agriculture, University of Lampung. Plant tissue analysis was conducted to quantify plant available $\mathrm{C}, \mathrm{N}, \mathrm{P}, \mathrm{K}, \mathrm{Ca}$, and $\mathrm{Mg}$. In addition to soil nutrient, plant and biomass dry weight of soybean was also measured.

\section{Predatory potential study}

Natural Enemy Exclusion Experiment. The impact of natural enemies on A. glycines abundance was measured in an exclosure (caged) experiment. Field experiments were conducted on $7 \times 12 \mathrm{~m}$ plot at the University of Lampung campus from July to November 2009. The soybean variety used in this experiment was Anjasmoro. Three seeds were planted per hole in $10 \mathrm{x}$ $40 \mathrm{~cm}$ spacing rows. After germination, the number of seedlings were reduced to two plants per hill to reduce competition. Four weeks after planting (V3 stage on the scale of Fehr \& Caviness (1977)), soybean plants were infested artificially with laboratory-reared $A$. glycines. Infestation was conducted by transferring aphids to the uppermost expanded trifoliate experimental plants by using a fine camel's hair brush. Treatments were caged plants (no natural enemies) and uncaged plants (with natural enemies). Each treatment was replicated three times. Cage frames of $0.80 \mathrm{~cm}$ in width by $0.90 \mathrm{~m}$ in length by $1 \mathrm{~m}$ in height were constructed from wooden poles and covered with very fine nylon mesh. Mesh was sewn to fit the cage frame with excess material on the bottom to allow the mesh to be buried. The bottom edge of cages (approximately $10 \mathrm{~cm}$ ) with excess mesh was buried in the soil to seal the cage. Control cages consisted of just the wooden poles frame without mesh. Control cages (uncaged plants) were designed to allow full access to all natural enemies, while caged plants were designed to eliminated all natural enemies. Cages were placed $1.5 \mathrm{~m}$ apart within the soybean field. Sampling consisted of weekly visual observations of the caged plants for soybean aphids and aphidophagous predators.

Predation effficiency experiment. The predation trial was conducted at the laboratory of Crop Pests, College of Agriculture, University of Lampung from July to November 2009. All the experiments were completed under laboratory conditions (temperature $25 \pm 5^{\circ} \mathrm{C}$ and R.H. $65 \pm 5 \%$ ). All insect test (A. glycines as prey and $C$. sexmaculata as predators) used in this study were taken from a laboratory colony that originated from fieldcollected insects, in Darma Agung Village, Seiputih Mataram District, Central Lampung, Lampung Province. At first, three seeds (of soybean variety Anjasmoro) were planted in $15-\mathrm{cm}$-diameter by $17-\mathrm{cm}-$ deep pots in a soil mixture containing sand, soil, and compost. After germination, the seedlings were thinned to one plant per pot to reduce competition. Plants were watered daily with tap water. After 2 weeks old, soybean plants were infested with soybean aphids and then confined in transparent plastic cage $(14 \mathrm{~cm}$ diameter and $30 \mathrm{~cm}$ high) with its top and sides cut off and covered with a fine mesh nylon net for air ventilation. The soybean aphids were reared on these plants in order to supply necessary insects for the experiment. At the same time, field collected predator $C$. sexmaculata were fed with soybean aphids on soybean leaf sections and allowed to breed. Egg clutches from each predator were kept individually in Petri dishes for hatching. Meanwhile, various densities of 10, 20, 40, 50, 75, 100, $150,200,250$, or 300 aphids were prepared for predatory treatments. Each aphid density was placed on soybean leaf sections in Petri dishes of $9 \mathrm{~cm}$ in diameter and 2 $\mathrm{cm}$ deep with a screened hole in the lid, and lined with a moistened filter paper. One larva or adult of predaceous coccinellid $C$. sexmaculata was transferred into each of the Petri dishes containing the aphids after $24 \mathrm{~h}$ starvation period. Three replications for each aphid density were employed. The predaceous coccinellids were allowed to feed on the offered prey density for 24 $\mathrm{h}$ and the remaining uneaten aphids were recorded.

Data Analysis. For soil nutrition experiment, means and SEs were calculated for soybean aphid densities, the plant performance (plant height, leaf numbers, pod numbers, dry weight per plant, and biomass dry weight) 
and for the plant chemical components $(\mathrm{N}, \mathrm{P}, \mathrm{K}, \mathrm{C}, \mathrm{Ca}$, and $\mathrm{Mg}$ ) for each of the treatments. The effects of soil nutrient treatments were analyzed by analysis of variance (ANOVA) (PROC GLM procedure) followed by comparisons of means by the Fisher protected least significant difference (LSD) test (significance level, $P$ $=0.05)$ (SAS Institute Inc., 1988). All plant performance results were presented graphically. In addition, a linear correlation analysis (PROG CORR procedure) using SAS program was performed to relate soybean aphids densities to plant nutrient variables $(\mathrm{C}$, $\mathrm{N}, \mathrm{P}, \mathrm{K}, \mathrm{Ca}$, and $\mathrm{Mg}$ ). For natural enemy exclusion experiment, mean number $( \pm S E)$ of soybean aphid on caged and uncaged treatments was also determined and presented in graphs. The effect of prey density on predatory efficiency of $C$. sexmaculata was analyzed by analysis of variance (PROC GLM procedure) followed by comparisons of means by the Fisher protected least significant difference (LSD) test (significance level, $P=0.05$ ) (SAS Institute Inc., 1988).

\section{RESULTS AND DISCUSSION}

Soil Nutrition Experiment. The results of this study demonstrated that soil nutrition treatments had significant effects on the plant performances: leaf numbers $(\mathrm{F}=7.13$; d.f. $=3,8 ; P>\mathrm{F}=0.0119)$; pod numbers $(\mathrm{F}=12.24$; d.f. $=3,8 ; P>\mathrm{F}=0.0023)$ and plant height $(\mathrm{F}=5.09$; d.f. $=3,8 ; P>\mathrm{F}=0.0293)$. Soybean plants fertilized with $100 \%$ chemical fertilizer NPK had 10.33 leaves in average and this number was significantly lower than that of other treatments: 17. 33 leaves at $75 \%$ NPK + comp.; 14.67 leaves at 50\% NPK $+50 \%$ comp. + dol., and 14.00 leaves at 50\% NPK level $+50 \%$ comp + CM (LSD $=3.5225 ; \mathrm{P}=0.05)$ (Figure 1). Moreover, pod numbers of soybean plant fertilized with $50 \%$ NPK $+50 \%$ comp. + CM treatment $(52.67$ pods) were significantly higher than that of $75 \% \mathrm{NPK}+$ comp. treatment ( 33.00 pods) and $100 \%$ NPK treatment (16.67 pods), however no significantly difference (48.00 pods) with $50 \% \mathrm{NPK}+50 \%$ comp. + dol. treatment (LSD $=15.17 ; \mathrm{P}=0.05)$. Meanwhile, plant height of soybean fertilized with 50\% NPK + 50\% comp. + CM treatment was $79.33 \mathrm{~cm}$ and this height was significantly taller than that of $100 \%$ NPK $(64.33 \mathrm{~cm})(\mathrm{LSD}=9.17$; $\mathrm{P}=0.05)$, but lack of significant differences when compared to 50\% NPK level + 50\% comp. + dol. (73.33 $\mathrm{cm})$ and $50 \%$ NPK level $+50 \%$ comp. + CM treatments $(79.33 \mathrm{~cm})$ (Figure 1). Umoetok et al. (2002) found similar results which indicated that both NPK and poultry manure significantly affected the plant height, number of pods per plant of soybean plants. In more detail, their results explained that plant height and pod numbers were significantly higher when inorganic fertilizer NPK was combined with poultry manure. The combination of inorganic fertilizer, compost, and chicken manure has a reasonable nutrient balance in the soils in which would be available for the soybean uptake (Lumbanraja, 2007). Moreover, the study by Altieri \& Nicholls (2003) showed that soil fertility management has several effects on plant quality, which in turn, will affect insect abundance and subsequently levels of herbivore damage. Other previous studies suggested that crops grown in soils with high organic matter and active soil biology generally exhibit lower abundance of several insect herbivores (Eigenbrode \& Pimentel, 1988; Feber et al., 1997; Karungi et al., 2006; Lockeretz et al., 1981; Reganold et al., 1987; Stanhill, 1990).

Regardless of the significant effect of treatments on the plant performances, there was no significant differences in soybean dry weight (kg per plant) $(\mathrm{F}=$ 1.79 ; d.f. $=3,8 ; P>\mathrm{F}=0.2268)$; and biomass dry weight $\left(\mathrm{kg} \mathrm{ha}^{-1}\right)(\mathrm{F}=1.78$; d.f. $=3,8 ; P>\mathrm{F}=0.2286)$ (Figure 2 ). This result indicated that despite different response of plant variables, soil nutrient treatments caused similar soybean growth. This finding suggested that decreasing synthetic fertilizer NPK by $50 \%$ can be compensated by natural organic materials such as composts and chicken manure. Past study by Karungi et al. (2006) showed that plant's biomass production accuring from composted soils were comparable and sometimes even higher than those of NPK treatments. More recent study conducted by Hsu et al. (2009) indicated that plants that received organic fertilizer had higher aboveground biomass accumulation compared with those with synthetic fertilizers.

The results of plant nutrient analyses on chemical components $(\mathrm{C}, \mathrm{N}, \mathrm{P}, \mathrm{K}, \mathrm{Ca}$, and $\mathrm{Mg}$ ) for each of the treatment were presented in Table 1. There were significant effects of soil nutrient treatments on the amount of plant nutrient: nitrogen level $(\mathrm{F}=25.86 ; P>$ $\mathrm{F}=0.0002)$; phosphorus level $(\mathrm{F}=7.33 ; P>\mathrm{F}=0.0133)$; potassium level $(\mathrm{F}=6.31 ; P>\mathrm{F}=0.0167)$; carbon level $(\mathrm{F}=127.68 ; P>\mathrm{F}=0.0001)$; calcium level $(\mathrm{F}=74.22$; $P>\mathrm{F}=0.0001)$; and magnesium level $(\mathrm{F}=24.25 ; P>\mathrm{F}$ $=0.0109)$. In general, the effects soil nutrient treatments on the amount of all plant chemical components varied (Table 1). The amount of carbon in plants treated with $75 \%$ NPK + comp. $(32.64 \%)$ and $50 \%$ NPK $+50 \%$ comp. + dol. (32.44\%) were significantly higher than that of $100 \%$ NPK $(28.72 \%)$ and $50 \%$ NPK $+50 \%$ comp. + CM (30.89\%). Nitrogen levels were 

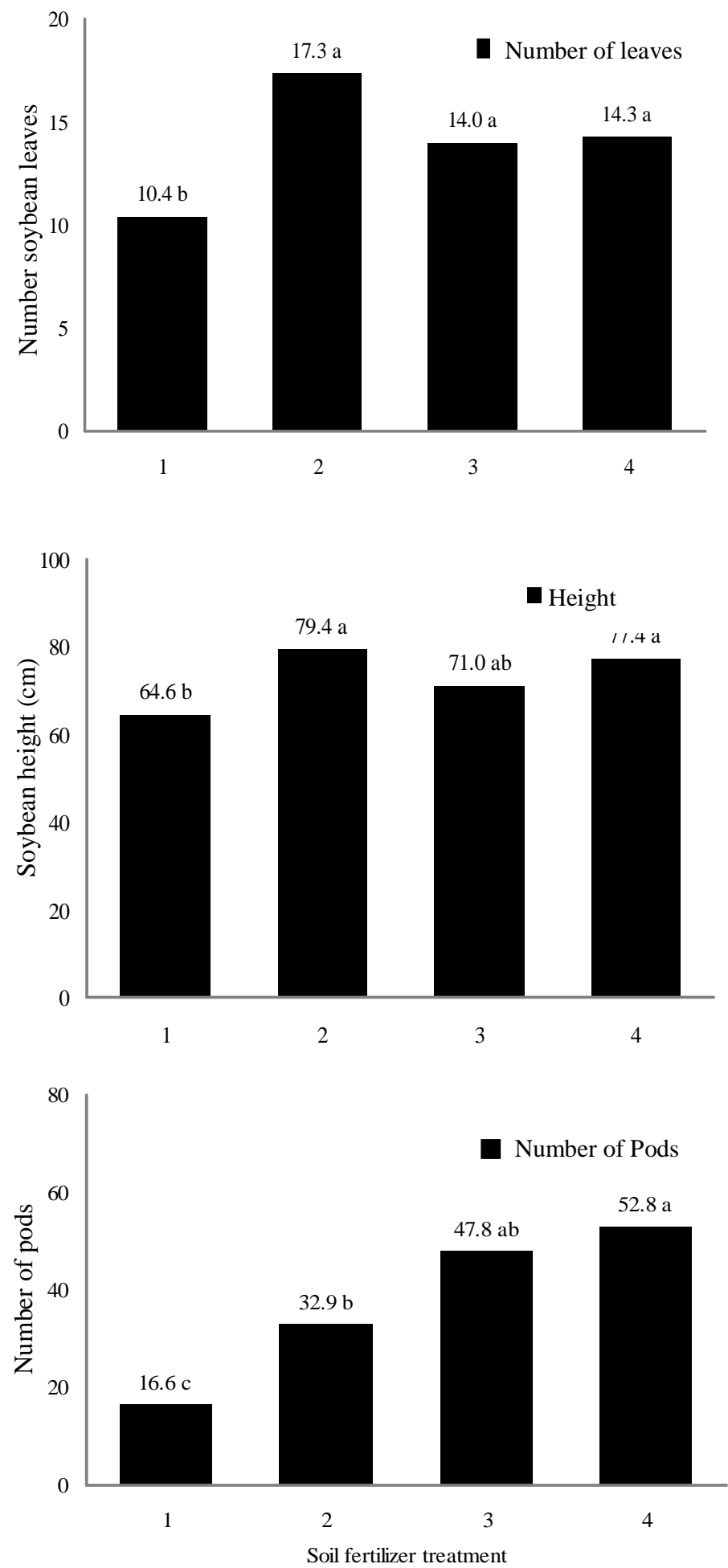

Figure 1. Mean numbers of soybean leaves per plant, plant height $(\mathrm{cm})$, and mean number pods per plant treated with different soil fertilizer: ( $1=100 \%$ chemical fertilizer NPK (urea $100 \mathrm{~kg} \mathrm{ha}^{-1}+$ SP-36 $200 \mathrm{~kg} \mathrm{ha}^{-1}+$ $\mathrm{KCl} 200 \mathrm{~kg} \mathrm{ha}^{-1} ; 2=75 \%$ chemical fertilizer NPK+ compost 20 ton ha ${ }^{-1} ; 3=50 \%$ chemical fertilizer $\mathrm{NPK}+$ compost 10 ton $\mathrm{ha}^{-1}+$ dolomite 4 ton $\mathrm{ha}^{-1} ; 4=50 \%$ chemical fertilizer NPK + compost 10 ton $\mathrm{ha}^{-1}+$ chicken manure 10 ton $\left.\mathrm{ha}^{-1}\right)$. Means with the same letter are not significantly different $(P=0.05)$ according to Fisher protected least significant difference (LSD) test using PROG GLM Procedure of SAS (SAS Institute Inc., 1988) 
significantly higher in the soybean plants treated with $100 \%$ NPK and 50\% NPK + 50\% comp. + CM. Moreover, the content of phosphorus in plants treated with $50 \%$ NPK + 50\% comp. + CM (2.80\%) was significantly higher compared to other treatments. Plants treated with 50\% NPK+ comp. + dol. had the highest calcium level $(0.35 \%)$, whereas the lowest amount of calcium $(0.28 \%)$ was obtained from the plant fertilized with $100 \%$ NPK. Finally, plants treated with 50\% NPK
+ 50\% comp. + CM contained highest magnesium level. Past study has indicated that the amount of $\mathrm{P}, \mathrm{K}, \mathrm{Ca}$, and $\mathrm{Mg}$ extracted from the soils treated with compost were higher than that from NPK plots (Karungi et al., 2006). According to Mattson (1980) and Okamoto \& Okada (2004), among the nutritional factors, nitrogen has been considered the most critical one to affect both plants and their consumers. Moreover van Emden (1966) reported that increases in fecundity and
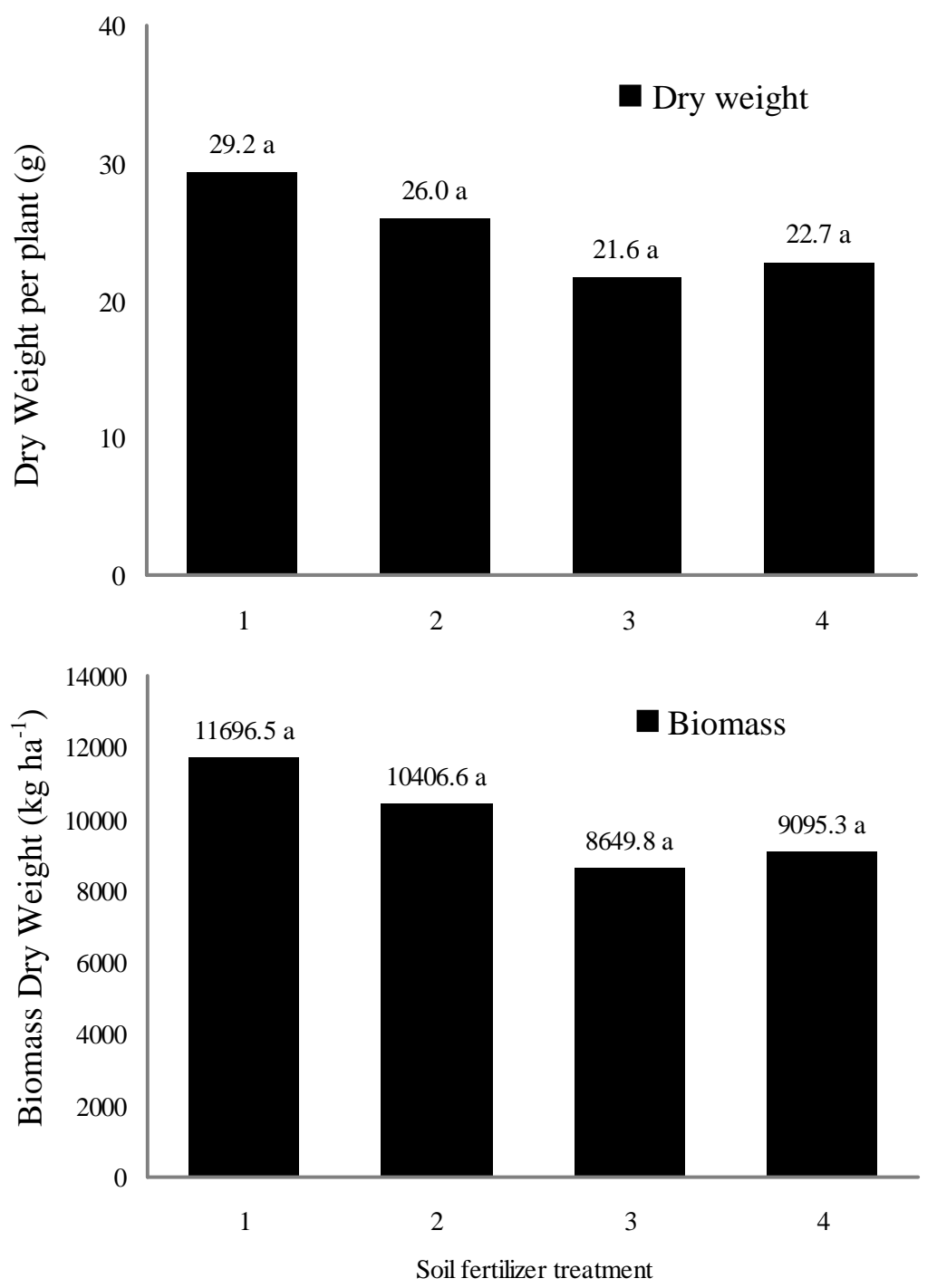

Figure 2. Mean soybean dry weight plant $(\mathrm{g})$ and total biomass dry weight treated with different soil fertilizer $\left(1=100 \%\right.$ chemical fertilizer NPK (urea $100 \mathrm{~kg} \mathrm{ha}^{-1}+\mathrm{SP}-36200 \mathrm{~kg} \mathrm{ha}^{-1}+\mathrm{KCl} 200 \mathrm{~kg} \mathrm{ha}^{-1} ; 2=75 \%$ chemical fertilizer NPK + compost 20 ton ha- ${ }^{-1} ; 3=50 \%$ chemical fertilizer NPK + compost 10 ton ha ${ }^{-1}$ + dolomite 4 ton ha' ${ }^{-1} ; 4=50 \%$ chemical fertilizer NPK + compost 10 ton ha' ${ }^{-1}+$ chicken manure 10 ton $\mathrm{ha}^{-1}$ ). Means bearing the same letter are not significantly different at the 5\% significance level according to Fisher protected least significant difference (LSD) test using PROG GLM Procedure of SAS (SAS Institute Inc., 1988) 
developmental rates of the green peach aphid, Myzus persicae, were highly correlated to increased levels of soluble nitrogen in leaf tissue. However, different results were reported by Myers et al. (2005) and Myers \& Gratton (2006) who found that potassium is one of important nutritional factors affecting plant quality and soybean aphid population dynamics.

Bioassay results indicated that soil nutrient treatment had a significant impact on soybean aphid population $(\mathrm{F}=5.99$; d.f. $=3,8 ; P>\mathrm{F}=0.0456)$. Soybean plants treated with $100 \%$ chemical fertilizer NPK were colonized by the highest aphid numbers (130.00 aphids per plant), and this density was significantly higher compared to other treatments. In contrast, it seemed that treatment 50\% NPK $+50 \%$ comp. + CM resulted in the lowest number of soybean aphids (Figure 3). Based on these results, it can be concluded that soil nutrient has an impact on nutritional elements in plant, that subsequently can affect susceptibility of plants to insect pests. Numerous studies have shown that the ability of a crop plant to resist or tolerate insect pests and diseases is tied to optimal physical, chemical and mainly biological properties of soils. Soils with high organic matter and high biological activity generally exhibit good soil (Berlandier \& Bwye, 1998; Brown \& Tworkoski 2004; Harrewijn \& Minks, 1989; Yardim \& Edwards, 2003; Wratten et al., 2007). Moreover Phelan et al. (1995) reported that reduced susceptibility of plants to pests was mediated by soil fertility management. According to Myers \& Gratton (2006), densities of soybean aphids populations were significantly affected by potassium (K) treatment. Low $\mathrm{K}$ levels tended to have the highest rates of soybean aphid population growth. Based on their studies, they provide strong evidence that variation in $\mathrm{K}$ plays an important role in influencing soybean aphid population dynamics. Meanwhile, Hu et al. (1992) found that there was a relationship between the nitrogen content in soybean leaves and occurrence degree of A. glycines. Soybean aphid populations increased as nitrogen content in leaves increased and decreased as nitrogen content in leaves decreased (Hu et al., 1992).

A linear correlation analysis was performed to understand the relationship between soybean aphid population and the plant performance (plant height, number of leaves, and number of pods). Number of soybean aphids was negatively correlated with plant variables: plant height, number of leaves, and number of pods (Figure 1; Table 2); however the significance levels among plant attibutes varied. Leaf numbers was weak $(P>|\mathrm{R}|=0.0603)$ negatively associated with soybean aphid infestation; whereas the strong $(P>|\mathrm{R}|$ $=0.0008)$ negative correlation was gained on pod numbers and aphid densities relationship (Table 2). This finding confirmed that soybean aphids infestation can reduce soybean plant performance. Soybean aphid populations have been reported to respond to nutrient availability in soybean (Hu et al., 1992; Qi et al., 1993; Myers et al., 2005; Myers et al., 2006; Sinclair \& de Wit, 1976). Umoetok et al. (2002) reported that higher synthetic fertilizer inputs may lead to higher levels of insect pests of soybean. Other previous studies have

Table 1. Levels of tissue nutrient of soybean plants treated with four different soil nutrient

\begin{tabular}{cccclll}
\hline Treatment* & $\mathrm{C}(\%)$ & $\mathrm{N}(\%)$ & $\mathrm{P}(\%)$ & $\mathrm{K}(\%)$ & $\mathrm{Ca}(\%)$ & $\mathrm{Mg}(\%)$ \\
\hline I & $28.72 \mathrm{c}^{* *}$ & $2.77 \mathrm{a}$ & $0.113 \mathrm{~b}$ & $0.56 \mathrm{c}$ & $0.28 \mathrm{~d}$ & $0.21 \mathrm{c}$ \\
II & $32.64 \mathrm{a}$ & $2.48 \mathrm{~b}$ & $0.113 \mathrm{~b}$ & $0.62 \mathrm{a}$ & $0.32 \mathrm{c}$ & $0.23 \mathrm{~b}$ \\
III & $32.44 \mathrm{a}$ & $2.53 \mathrm{~b}$ & $0.103 \mathrm{~b}$ & $0.56 \mathrm{bc}$ & $0.39 \mathrm{a}$ & $0.24 \mathrm{~b}$ \\
IV & $30.89 \mathrm{~b}$ & $2.80 \mathrm{a}$ & $0.130 \mathrm{a}$ & $0.59 \mathrm{ab}$ & $0.35 \mathrm{~b}$ & $0.25 \mathrm{a}$ \\
LSD Value & 0.5231 & 0.1058 & 0.0133 & 0.0407 & 0.0163 & 0.0109 \\
\hline
\end{tabular}

* I $=100 \%$ chemical fertilizer NPK (urea $100 \mathrm{~kg} \mathrm{ha}^{-1}+$ SP-36 $200 \mathrm{~kg} \mathrm{ha}^{-1}+\mathrm{KCl} 200 \mathrm{~kg} \mathrm{ha}^{-1} ; \mathrm{II}=75 \%$ chemical fertilizer NPK + compost 20 ton $\mathrm{ha}^{-1}$; III $=50 \%$ chemical fertilizer NPK + compost 10 ton ha ${ }^{-1}+$ dolomite 4 ton ha $\mathrm{h}^{-1} ; \mathrm{IV}=50 \%$ chemical fertilizer NPK + compost 10 ton ha ${ }^{-1}+$ chicken manure 10 ton ha $\left.\mathrm{h}^{-1}\right)$.

**Within a column, means followed by the same letters are not significantly different $(\mathrm{P}=0.05$; LSD) test using PROG GLM Procedure of SAS (SAS Institute Inc., 1988). 
shown that soybean aphid infestations may also cause leaf yellowing and curling, plant stunting reduced branch number, lower pod and seed counts, reduced seed weight, and, under severe infestations, plant death (Blackman \& Eastop 2000; Dixon, 1977; Macedo et al., 2003; Li et al., 2000; Ragsdale et al., 2004; 2007; Wu et al., 1999). Moreover Wang et al. (1994) found that the number of soybean aphids per plant was negatively correlated with plant height, number of pods, and number of seeds per plant of soybean.

A linear correlation analysis was performed to understand the relationship between soybean aphid population and plant nutrients and the results were presented in Table 3. In general, there were negative correlations between soybean aphid infestation and plant nutrient level except nitrogen; however, the correlation coefficient ( $\mathrm{r}$ ) of nitrogen with aphid density was not significant $(\mathrm{r}=0.17051 ;$ Prob $>|\mathrm{R}|=0.5962)$ (Table 2). The significant negative association only found on correlation between aphid infestation and the amount of calcium ( $\mathrm{r}=-0.73571$; Prob $>|\mathrm{R}|=0.0064)$ and magnecium $(\mathrm{r}=-0.89360$; Prob $>|\mathrm{R}|=0.0001)$. The positive correlation coeficient between the aphid population and nitrogen content of the soybean indicating higher protein content of the soybean that can be easily attacked by aphids (Hu et al., 1992; Sinclair \& de Eith, 1976; Munier-Jolain et al., 1996). While the significant negative found on correlation between aphid infestation and the calcium and magnesium content would be due to the hardness. The hardness of the soybean tissues due to the the high $\mathrm{C} / \mathrm{N}$ ratios, the high calcium and magnesium content on which could not easily attack soybean plants (Qi et al., 1993; Sinclair \& de Eith, 1976; Munier-Jolain et al., 1996).

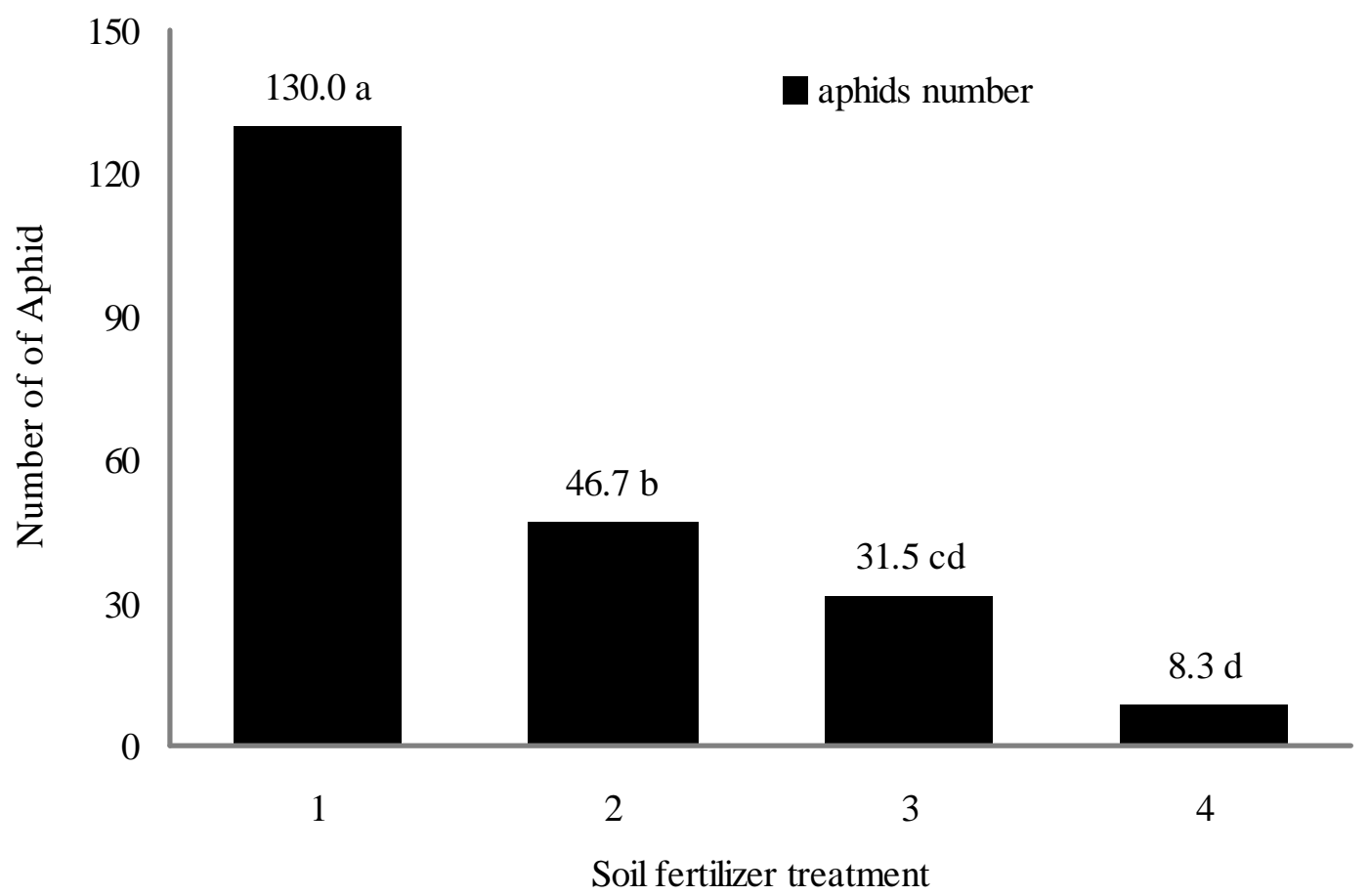

Figure 3. Mean soybean aphids, Aphis glycines, per plant treated with different soil fertilizer: $(1=100 \%$ chemical fertilizer NPK (urea $100 \mathrm{~kg} \mathrm{ha}^{-1}+\mathrm{SP}-36200 \mathrm{~kg} \mathrm{ha}^{-1}+\mathrm{KCl} 200 \mathrm{~kg} \mathrm{ha}^{-1} ; 2=75 \%$ chemical fertilizer NPK+ compost 20 ton ha ${ }^{-1} ; 3=50 \%$ chemical fertilizer NPK + compost 10 ton ha ${ }^{-1}+$ dolomite 4 ton $\mathrm{ha}^{-1} ; 4=50 \%$ chemical fertilizer NPK + compost 10 ton ha ${ }^{-1}+$ chicken manure 10 ton ha $\left.{ }^{-1}\right)$. Means bearing the same letter are not significantly different at the 5\% significance level according to Fisher protected least significant difference (LSD) test 


\section{Predatory Potential Study}

Natural Enemy Exclusion Experiment. The impact of natural enemies was assessed by using predator exclusion cages in which mean number of A. glycines densities were compared in cages (no natural enemies) and without cages (natural enemies impact). In the nocage treatments, naturally occurring biological agents (natural enemies) had complete access to soybean aphids, A. glycines; whereas in the caged treatments, natural enemies had no access to soybean aphids. In general, the results indicated that mean number of soybean aphids in caged plants was higher than that in uncaged plants. After infestations at the V2 growth stage, populations in both caged and uncaged plants began rising. Prior to infestation, no soybean aphids were observed in any exclusion cages. Within a second week period, aphid density in exclusion cages increased steadily, reaching at 186.50 aphids per plant, whereas uncaged plant was only infested 173.23 in average. At this time soybean plants at the V3 stage that has three fully expanded trifoliates (Fehr \& Caviness, 1977). From this time, A. glycines populations in exclusion cages increased dramatically, peaking at 649.75 aphids per plant, at the V7-R1growth stage, while in the uncage plants, the peak soybean aphids densities only 205.00 aphids per plant at the V5 growth stage.
During trials, it was observed that natural enemy communities of $A$. glycines are primarily dominated by predators. Among those predators of A. glycines, Cheilomenes sexmaculata (Fabr.) (Coleoptera: Coccinellidae) was the most important soybean aphid natural enemy. This finding was supported by several scientists who have indicated that $C$. sexmaculata was the most commonly occurring predator in the soybean field (Rutledge et al., 2004; Rutledge \& O Neil, 2005; Stary, 1995). Moreover, van den Berg (1997) reported that that predators are a key source of soybean aphid mortality and can significantly reduce aphid population density. Other study by Mannan et al. (2001) also indicated that potato aphid, Myzus persicae (Sulzer) were completely controlled by the predator Menochilus sexmaculatus (Fab.). Near similar results were also found by the study Shingh \& Marwa (2002) in which they showed that the zigzag predaceous beetles, C. sexmaculata is an efficient biocontrol agents against maize aphids Rhopasopiphum maidis.

Predation efficiency experiment. The predation potential of $C$. sexmaculata was determined by the counting of total number of soybean aphids consumed by each predator. In general, the mean number of soybean aphids consumed by $C$. sexmaculata increased

Table 2. Correlation coefficient (r) between the plant performance (plant height, leaf numbers, pod numbers) ( $n=12$ soybean plots) and the mean number of soybean aphid

\begin{tabular}{ccc}
\hline Plant Performance & Correlation coefficient $(\mathrm{r}) *$ & Prob $>|\mathrm{R}|$ \\
\hline Leaf numbers & -0.55640 & 0.0603 \\
Pod numbers & -0.83175 & 0.0008 \\
Plant height & -0.62584 & 0.0295 \\
\hline
\end{tabular}

* a linear correlation analysis using PROC CORR Procedure of SAS (SAS Institute Inc., 1988).

Table 3. Correlation coefficient (r) between mean soybean plant nutrient levels ( $n=12$ soybean plots) and the mean number of soybean aphid treated with different soil nutrient level

\begin{tabular}{ccc}
\hline Plant Nutrient & Correlation coefficient $(\mathrm{r})$ & Prob $>|\mathrm{R}|$ \\
\hline $\mathrm{C}$ & -0.68766 & 0.0135 \\
$\mathrm{~N}$ & 0.17051 & 0.5962 \\
$\mathrm{P}$ & -0.18788 & 0.5587 \\
$\mathrm{~K}$ & -0.42582 & 0.1675 \\
$\mathrm{Ca}$ & -0.73571 & 0.0064 \\
$\mathrm{Mg}$ & -0.89360 & 0.0001 \\
\hline
\end{tabular}

* a linear correlation analysis using PROC CORR Procedure of SAS (SAS Institute Inc., 1988). 


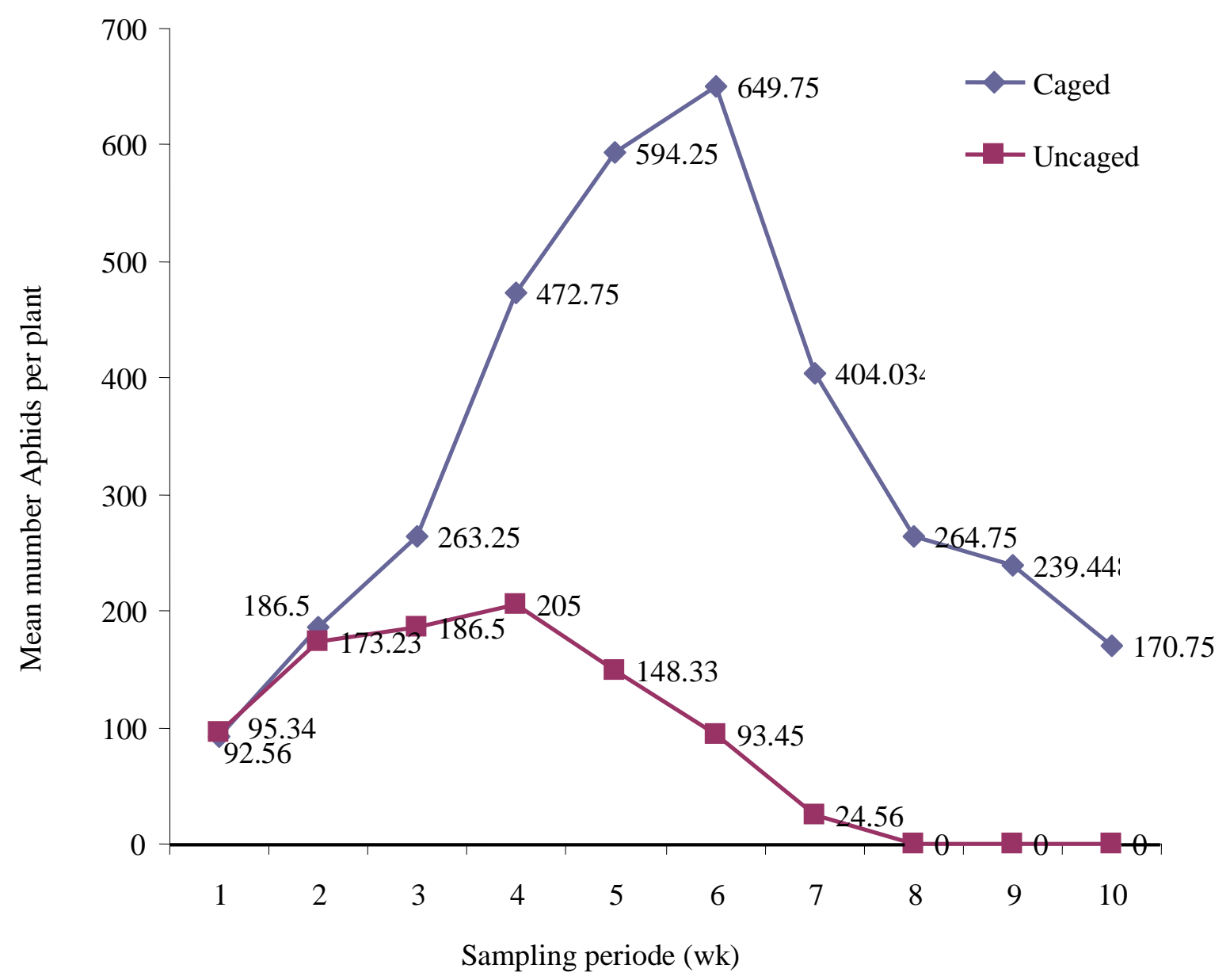

Figure 4. Population dynamics of A. glycines under natural enemy exclosure cage and without natural enemy (uncaged treatment)

from 8.915 to 40.64 aphids, with an average $26.35 \pm$ 3.16 aphids (Figure 5). The results indicated that the number of soybean aphids killed by $C$. sexmaculata increased in response to the increase in the population of aphid prey. The trend of the predation efficiency was clearly noticed by the graph of Figure 5 showing that the rate of predation was gradually increased as the density of prey increased. Other similar result was also reported by the study of Tenhumberg (1995) who indicated that the predatory efficiency of coccinellid beetles was directly proportional to aphid population. Moreover Agarwala \& Bardhanroy (1999) showed that C. sexmaculatus consumed more aphids (Aphis craccivora) as prey density increased. However, Patnaik \& Sahu (1980) reported that the effectiveness of $C$. sexmaculata as a predator declined when aphid prey are scarce.

In this study, the statistical analysis indicated that the mean numbers of aphids consumed by predator were significantly influenced by prey densities $(\mathrm{F}=10.58$; df $=5,12 ; \mathrm{P}<0.0013)$ (Figure 5). The number of aphids consumed (8.915) at low level of prey density (10 aphids per dish) treatment was significantly lower than those of prey density treatments, except with that (14.64) of (20 aphids per dish) treatment. Moreover, the highest number of aphids consumed (40.64) was observed at the highest prey density treatment (60 aphids per dish), this number was significantly higher than those of prey density treatments, except with that (37.44) of (50 aphids per dish) treatment (Figure 5). 


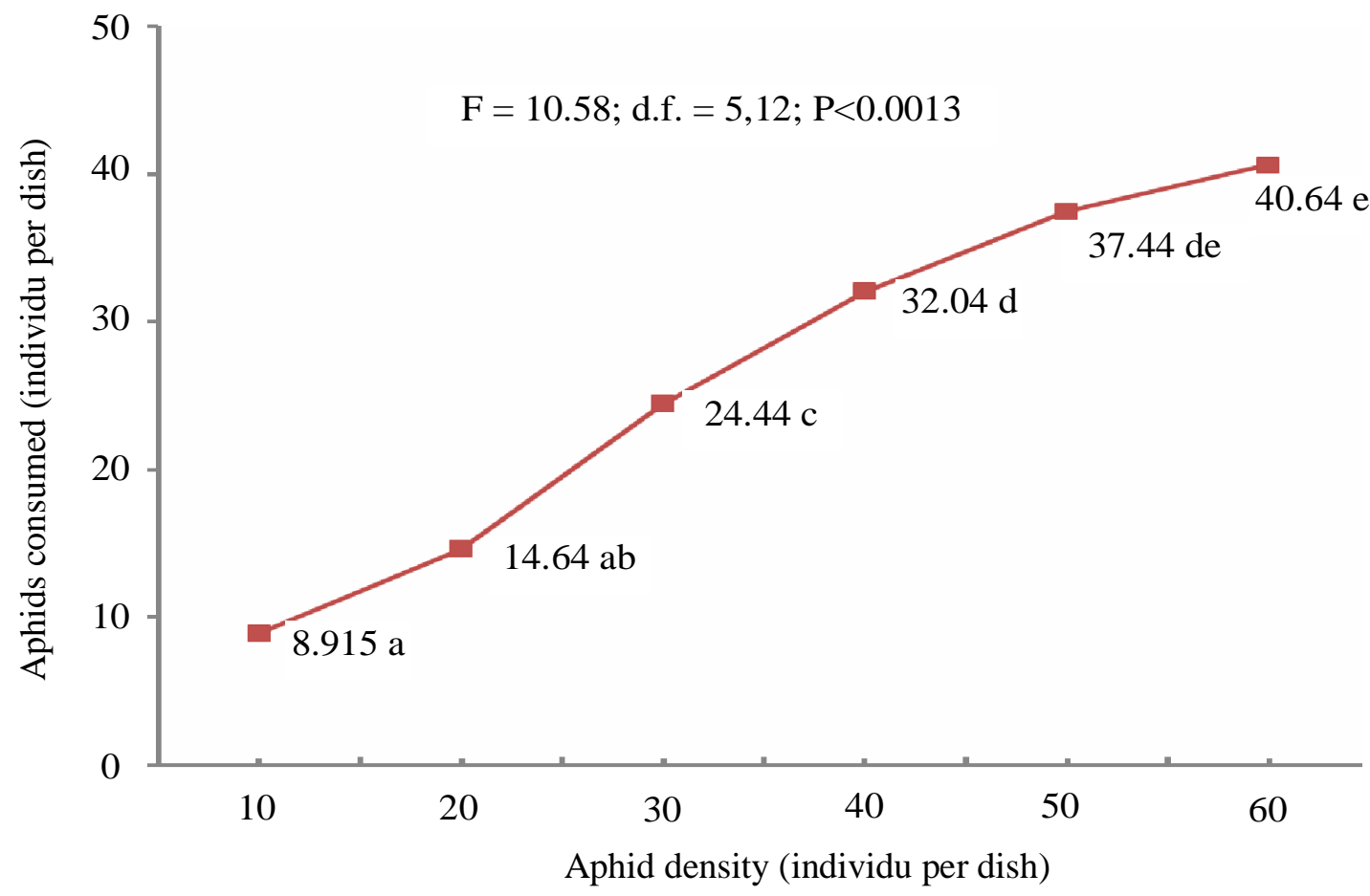

Figure 5. Numbers of soybean aphids, A. glycines, consumed by predaceous coccinellid $C$. sexmaculata adult at increasing prey density. Number bearing the same letter are not significantly different at the 5\% significance level according to Fisher protected least significant difference (LSD) test

This result was near similar to what has been reported by Mari et al. (2005) who found that the feeding rate per life stage of the Menochilus sexmaculatus on alfalfa aphid Therioaphis trifolii (Monell) for all four instars was 86.5, 115.2, 164.9 and 948.1, respectively, while at adult stage, both the males and the females consumed 88.2 and 99.21 on $18^{\text {th }}$ day, respectively and 60.5 and 61.90 aphids on $30^{\text {th }}$ day of their age. However, different result was found by Agarwala et al. (2001) who found that the prey consumption of the M. sexmaculatus on Aphis craccivora were highest at lower aphid densities suggesting that this ladybird species exploit prey efficiently at low density. More different result was also reported by Natapol \& Pensook (1988) who indicated that the average predation capacity of Menochilus sexmaculatus in its adult stage of male and female were 1012.7 and 1109.9 A. glycines respectively. Those varied results suggested that the predatory efficiency of $C$. sexmaculata depended on: density of the prey; stage of the prey, mobility of the prey, and species of the prey.

\section{CONCLUSION}

The results of the study indicated that the soil nutrition treatments had significant effects on the plant performances: leaf numbers; pod numbers; and plant height. This finding suggested that reducing the amount of synthetic chemical fertilizer NPK can be supplemented with natural organic materials such as composts and chicken manure. Moreover, this study revealed that the increasing of the aphid population in soybean is following with the increasing nitrogen content of the soybean due to the higher protein content of soybean, especially in the young leaves and shoots, while the significant negative found on correlation between aphid infestation and the calcium and magnesium content would be due to the hardness of the soybean tissue. While the field trials indicated that predaceous coccinellid, Cheilomenes sexmaculata, was the most commonly occurring predator in the soybean field. The impact of naturally occurring biological control agents show that the density of A. glycines in caged plants was higher than that in uncaged plants. Moreover, 
laboratory studies indicated that the number of soybean aphids killed by $C$. sexmaculata increased in response to the increase in the population of aphid prey. This study suggested that the predator $C$. sexmaculata is one of important natural enemies of soybean aphids and considered to be an efficient biocontrol agents against soybean aphids. Gaining a better understanding of the relationship between soil nutrition management (cultural control) and natural enemies (biological control) will be critical for developing integrated pest management (IPM) strategy against $A$. glycines.

\section{REFERENCE}

Altieri MA \& Nicholls CI. 2003. Soil fertility management and insect pests: harmonizing soil and plant health in agroecosystems. Soil and Tillage Research 72: 203-211.

Agarwala BK \& Bardhanroy P. 1997. Oviposition behaviour and reproduction efficiency in ladybird beetles a case study of Menochilus sexmaculatus (Fabr.). J. Aphidol. 11: 1-10.

Agarwala BK \& Bardhanroy P. 1999. Numerical response of ladybird beetles (Col., Coccinellidae) to aphid prey (Hom., Aphididae) in a field bean in north-east India. J. Appl. Entomol. 123: 401-405.

Agarwala BK \& Yasuda H. 2000. Competitive ability of ladybird predators of aphids; A review of Cheilomenes sexmaculata (Fabr.) (Coleoptera: Coccinellidae) with a wordwide checklist of preys. J. Aphidol. 14: 1-20.

Agarwala BK, Bardhanroy P, Yasuda H \& Takizawa T. 2001. Prey Consumption and Oviposition of the Aphidophagous Predator Menochilus sexmaculatus (Coleoptera: Coccinellidae) in Relation to Prey Density and Adult Size. Environ. Entomol. 30(6): 1182-1187.

Alyokhin A \& Atlihan R. 2005. Reduced fitness of the Colorado potato beetle on potato plants grown in manure-amended soil. Environ. Entomol. 34: 963-968.

Bind RB. 1998. Prey preference of a ladybird beetle Cheilomenes (=Menochilus) sexmaculata (Fabr.). J. Aphidol. 12: 63-66.
Blackman RL \& Eastop VF. 2000. Aphids on the worlds crops: an identification and information guide. Wiley, New York.

Brosius TR, Higley LG, \& Hunt TE. 2007. Population dynamics of soybean aphid and biotic mortality at the edge of its range. J. Econ. Entomol. 100: $1268-1275$.

Burrows MEL, Boerboom CM, Gaska JM \& Grau CR. 2005. The relationship between Aphis glycines and soybean mosaic virus incidence in different pest management systems. Plant Dis. 89: 926934.

Cartwright B, Eikenbary RD, Johnson JW, Farris TN \& Morrison RD. 1977. Field release and dispersal of Menochilus sexmaculatus, an important predator of the greenbug, Schizaphis graminum. Environ. Entomol. 6: 699-704.

Eigenbrode SD \& Pimentel D. 1988. Effects of manure and chemical fertilizers on insect pest populations on collards. Agric. Ecosyst. Environ. 20: 199125 .

Feber RE, Firbank LG, Johnson PJ \& Macdonald DW. 1997. The effects of organic farming on pest and non-pest butterfly abundance. Agric. Ecosyst. Environ. 64: 133-139.

Fernandez-Cornejo J. 1996. The microeconomic impact of IPM adoption: theory and application. Agric. Resour. Econ. Rev. 25: 149-160.

Fernandez-Cornejo J. 1998. Environmental and economic consequences of technology adoption: IPM in viticulture. Agric. Econ. 18: 145-155.

Fox TB, Landis DA, Cardoso FF \& DiFonzo CD. 2004. Predators suppress Aphis glycines Matsumura population growth in soybean. Environ. Entomol. 33: 608-618.

Halbert SE, Zhang GX \& Pu ZQ. 1986. Comparison of sampling methods for alate aphids and observation on epidemilogy of soybean mosaic virus in Nanjing, China. Ann. Appl. Biol. 109: 473-483. 
Hill JH, Alleman HR, Hogg B \& Grau CR. 2001. First report of transmission of Soybean mosaic virus and Alfalfa mosaic virus by Aphis glycines in the New World. Plant Dis. 85: 561.

Hill JH, Bailey TH, Benner HI, Tachibana H \& Durand DP. 1987. Soybean mosaic virus: Effects of primary disease incidence on yield and seed quality. Plant Dis. 71(3): 237-239.

Hsu YT, Shen TC \& Hwang SY. 2009. Soil Fertility Management and Pest Responses: A Comparison of Organic and Synthetic Fertilization. J. Econ. Entomol. 102(1): 160-169.

Hu Q, Zhang W, Yao Y \& Yan S. 1992. The relationship between the nitrogen content in soybean leaves and occurrence degree of Aphis glycines Matsumura. J. Jilin Agric. Univ. 14: 103-104.

Hussaein MY. 1991. Menochilus sexmaculatus Fabr. (Coleoptera: Coccinellidae) its biology, prey requirement and artificial diet. J. Plant Prot. 8: 153-160.

Irwin ME, Ruesink WG, Isard SA \& Kampmeier GE. 2000. Mitigating epidemics caused by nonpersistently transmitted aphid-borne viruses: the role of pliant environment. Virus Research 71: 185-211.

Johnson KD, O'Neal ME, Bradshaw J \& Rice M. 2008. Is preventative, concurrent-management of the soybean aphid (Hemiptera: Aphididae) and bean leaf beetle (Coleoptera: Chrysomelidae) possible? J. Econ. Entomol. 101: 801-809.

Jotwani MG \& Verma KK. 1969. Cheilomenes sexmaculata (Fabr.) as a predator of sorghum stem borer Chilozonellus (Swinnoe). Indian J. Entomol. 31: 84-85.

Karungi J, Ekbom B \& Kyamanywa S. 2006. Effects of organic versus conventional fertilizer on insect pests, natural enemies and yield of Phaseolus vulgaris. Ag., Eco, \& Environ. 115: 51-55.

Kraiss H \& Cullen EM. 2008. Efficacy and Nontarget Effects of Reduced-Risk Insecticides on Aphis glycines (Hemiptera: Aphididae) and Its Biological Control Agent Harmonia axyridis
(Coleoptera: Coccinellidae). J. Econ. Entomol. 101(2): 391-398.

Letourneau DK, Drinkwater LE \& Shennan C. 1996. Effects of soil management on crop nitrogen and insect damage in organic vs. conventional tomato fields. Agric. Ecosyst. Environ. 57: 179-187.

Liun J, Wu K, Hopper KR \& Zhao K. 2004. Population dynamics of Aphis glycines (Homoptera: Aphididae) and its natural enemies in soybean in northern China. Ann. Entomol. Soc. Am. 97: 235239.

Lockeretz W, Shearer G \& Kohl DH. 1981. Organic farming in the corn belt. Science 211: 540-546.

Lumbanraja J. 2007. Agricutural use of compost in Indonesia. Pp. 95-104. In: Proceedings of the $1^{\text {st }}$ International Meeting for the Development of IPM in Asia and Africa. Chiang Mai, Thailand, November 26-28, 2007.

Magalhaes LC, Hunt TE \& Siegfried BD. 2009. Efficacy of Neonicotinoid Seed Treatments to Reduce Soybean Aphid Populations Under Field and Controlled Conditions in Nebraska. J. Econ. Entomol. 102(1): 187-195.

Magalhaes LC, Hunt TE \& Siegfried BD. 2008. Development of methods to evaluate susceptibility of soybean aphid to imidacloprid and thiamethoxam at lethal and sublethal concentrations. Entomol. Exp. Appl. 128: 330336.

Mignault MP, Roy M \& Brodeur J. 2006. Soybean aphid predators in Québec and the suitability of Aphis glycines as prey for three Coccinellidae. BioControl 51: 89-106.

Mannan MA, Islam KS \& Jahan M. 2001. Effect of the predator, Menochilus sexmaculatus (Fab.) in controlling potato aphid, Myzus persicae (Sulzer). Pak. J. Sci. Res. 44: 101-104.

Mari JM, Rizvi NI, Nizami SM, Qureshi K, \& Lohar MK. 2005. Predatory efficiency of Menochilus sexmaculata Fab. and Coccinella undecimpunctata Lin., (Coccinellidae: 
Coleoptera) on alfalfa aphid, Therioaphis trifolii (Monell.). Asian J. Plant Sci. 4(4): 365-369.

Mattson WJ. 1980. Herbivory in relation to plant nitrogen content. Annu. Rev. Ecol. Syst. 11: 119161.

McCornack BP, Costamagna AC \& Ragsdale DW. 2008. Within-Plant Distribution of Soybean Aphid (Hemiptera: Aphididae) and Development of Node-Based Sample Units for Estimating WholePlant Densities in Soybean. J. Econ. Entomol. 101(4): 1488-1500.

Merrill MC. 1983. Eco-agriculture: a review of its history and philosophy. Biol. Agric. Hortic. 1: 181-210.

Meyer GA. 2000. Interactive effects of soil fertility and herbivory on Brassica nigra. Oikos 22: 433-441.

Mattson Jr WJ. 1980. Herbivory in relation to plant nitrogen content. Annu. Rev. Ecol. Syst. 11: 119161.

Myers SW, Hogg DB \& Wedberg JL. 2005a. Determining the optimal timing of foliar insecticide applications for control of soybean aphid (Hemiptera: Aphididae) on soybean. J. Econ. Entomol. 98: 2006-2012.

Myers SW, Gratton C, Wolkowski RP, Hogg DB \& Wedberg JL. 2005b. Effect of soil potassium availability on soybean aphid (Hemiptera: Aphididae) population dynamics and soybean yield. J. Econ. Entomol. 98: 113-120.

Munier-Jolain NG, Ney B \& Duthion C. 1996. Termination of growth in relation to nitrogen content of vegetative parts in soybean plants. Eur. J. Agron. 5: 219-225.

Napthapol W \& Pensook TT. 1988. Preliminary study on the predaceous coccinellid (Menochilus sexmaculatus $\mathrm{F}$.) in the control of groundnut aphids (Aphis glycines). Khon kaen Univ. Khon kaen (Thailand). Pp. 261-266. In: Proceeding of the Seventh Thailand National Groundnut Meeting.
Obrycki JJ \& Kring TJ. 1998. Predaceous coccinellidae in biological control. Annu. Rev. Entomol. 43: 295-321.

Oelhaf RC. 1978. Organic agriculture. Halstead Press, New York.

Ohnesorg WJ, Johnson KD \& NeaL M. 2009. Impact of Reduced-Risk Insecticides on Soybean Aphid and Associated Natural Enemies. J. Econ. Entomol. 102(5): 1816-1826.

Omkar \& Bind RB. 2004. Prey quality dependent growth, development and reproduction of a biocontrol agent, Cheilomenes sexmaculata (Fabricius) (Coleoptera: Coccinellidae). Biocont. Sci.Tech. 14(7): 665-673.

Patnaik NC \& Sahu DC. 1980. Influence of Aphid Host and Certain Artificial Diet on Ovipositional Response and Longevity of Ladybird Beetle, Menochilus sexmaculata (Fabr.) (Coleoptera: Coccinellidae). Sci. Cult. 46: 103-105.

Phelan PL, Mason JF \& Stinner BR. 1995. Soil fertility management and host preference by European corn borer, Ostrinia nubilalis, on Zea mays: a comparison of organic and conventional chemical farming. Agric. Ecosyst. Environ. 56: 1-8.

Qi H, Zhao J \& Jianwen C. 1993. The relationships between the level of lignin, the secondary metabolite in soybean plant and the aphid resistance in soybean. Plant Prot. 19: 8-9.

Ragsdale DW, McCormack BP, Venette RC, Potter BD, MacCrae IV, Hodgson EW, O'NeaL ME, Johnson KD, O'Neil RJ, Difonzo CD, Hunt TE, Glogaza PA \& Cullen EM. 2007. Economic threshold for soybean aphid (Hemiptera: Aphididae). J. Econ. Entomol. 100: 1258-1267.

Reganold JP, Elliott LF \& Unger YL. 1987. Longterm effects of organic and conventional farming on soil erosion. Nature (Lond.) 330: 370-372.

Rutledge CE, O’Nei RJ, Fox TB \& Landis DA. 2004. Soybean aphid predators and their use in integrated pest management. Ann. Entomol. Soc. Am. 97: 240-248. 
Rutledge C E.\& O’Neil RJ 2006. Soybean Plant Stage and Population Growth of Soybean Aphid. $J$. Econ. Entomol. 99(1): 60-66.

Scow KM, Somoasco O, Gunapala N, Lau S, Venette R, Ferris H, Miller R \& Shennan C. 1994. Transition from conventional to low-input agriculture changes soil fertility and biology. Calif. Agric. 48: 20-26.

Sinclair TR \& de Wit CT. 1976. Analysis of the carbon and nitrogen limitations to soybean yield. Agron. J. 68: 319-324.

Singh MR \& Marwaha KK. 2002. Feeding potential of some effective predators against maize aphid, Rhopalosiphum maides (Fitch.) Shaspha India. 9: 89-91.

Stanhill G. 1990. The comparative productivity of organic culture. Agric. Ecosyst. Environ. 30: 1-26.

SAS Institute. 2004. SAS/STAT user of guide, version 6.12. SAS Institute, Cary, NC.

Sugiura K \& Takada H. 1998. Suitability of seven aphid species as prey of Cheilomenes sexmaculatus (Fabricius) (Coleoptera: Coccinellidae). Jpn. J. Appl. Entomol. Zool. 42: 7-14.
Tenhumberg B. 1995. Estimation of predatory efficiency of Episyrphus balteatusbin cereal fields. Environ. Entomol. 24: 687-691.

Umoetok SBA, Uko AE, Archibong BE, Ukeh DA, Udo IA. 2002. Effect of application of inorganic fertilizer and poultry manure on insect pests and yield of soybean (Glycine max L.) in the rain forest zone of Nigeria. Entomol. Experim. Appl. 104: 109-116.

van den Berg H, Ankasah D, Mahammad A, Rusli R, Widayanto HA, Wirasto HB \& Yully I. 1997. Evaluating the role of predation in population fuctuations of the soybean aphid Aphis glycines in farmer fields in Indonesia. J. Appl. Ecol. 34: 971-984.

Wang S, Shen DA \& Ma ZQ. 1993. Insecticide influence on populations of major insect pests and natural enemies at the soybean seedling stage. Entomol. Knowl. 30: 333-335.

Wang RY \& Ghabrial SA. 2002. Effect of aphid behavior on efficiency of transmission of Soybean mosaic virus by the soybean-colonizing aphid, Aphis glycines. Plant Dis. 86: 1260-1264.

Wu Z, Schenk-Hamlin D, Zhanb W, Ragsdale DW \& Heimpel GE. 2004. The soybean aphid in China: a historical review. Ann. Entomol. Soc. Am. 97: 209-218.

Zehnder G, Gurr GM, Kuhne S, Wade MR, Wratten SD $\&$ Wyss E. 2007. Arthropod pest management in organic crops. Annu. Rev. Entomol. 52: 57-80. 